\title{
Helicobacter pylori in the oral mucosa of patients submitted to allogeneic haematopoietic stem cell transplantation
}

\section{Helicobacter pylori na mucosa oral de pacientes submetidos ao transplante de células-tronco hematopoiéticas}

\author{
Jeane de Fátima Correia-Silva* \\ Júnia Maria Neto Victória* \\ André Luiz Sena Guimarães* \\ Alessandra Rosa de Sá* \\ Carolina Cavaliéri Gomes* \\ Humberto Corrêa de Almeida** \\ Ricardo Santiago Gomez*
}

\begin{abstract}
This study was designed to investigate the impact of haematopoietic stem cell transplantation (HSCT) on Helicobacter pylori colonization of the oral mucosa by nested polymerase chain reaction (nested-PCR). Forty six consecutive patients submitted to HSCT and 46 healthy volunteers were included in the study. Oral swabs were taken from the oral mucosa of the patients and control group. The medical records of the patients were reviewed and the following information was retrieved: gender and age of the patient, donor gender, primary disease, stem cell source (bone marrow or blood stem cells), leukocyte, neutrophil and platelet counts, and chronic graft versus host disease (cGVHD) of salivary glands. The results demonstrated an increased frequency of $H$. pylori in the oral mucosa of HSCT patients compared to controls $(\rho=0.002)$. The presence of $H$. pylori in the oral mucosa was not related to the severity of cGVHD. The median counts of platelet $/ \mathrm{mm}^{3}$, leukocytes $/ \mathrm{mm}^{3}$ and neutrophils $/ \mathrm{mm}^{3}$ in the group of HSCT patients positive for $H$. pylori were not statistically different from those of the patients negative for it. In conclusion, the present study shows increased frequency of $H$. pylori in the oral mucosa of HSCT patients compared to non-transplanted healthy volunteers.
\end{abstract}

DESCRIPTORS: Helicobacter pylori; Bone marrow transplantation; Mouth mucosa.

RESUMO: O objetivo do estudo é investigar o impacto do transplante de células-tronco hematopoiéticas (TCTH) na colonização da mucosa bucal pela Helicobacter pylori através do "nested-PCR". Quarenta e seis pacientes submetidos ao TCTH e 46 indivíduos saudáveis foram incluídos no estudo. Raspados de mucosa bucal foram realizados nos pacientes do grupo de estudo e grupo controle. Os dados médicos dos pacientes foram revisados e as seguintes informações foram coletadas: gênero e idade do paciente, gênero do doador, doença primária, fonte de células-tronco (medula óssea ou células-tronco sanguíneas), número de leucócitos, neutrófilos e plaquetas, doença do enxerto contra o hospedeiro crônica ( $\mathrm{DECHc}$ ) de glândulas salivares. Os resultados demonstram aumento na freqüência de $H$. pylori na mucosa bucal de pacientes submetidos ao TCTH comparado com grupo controle $(\rho=0.002)$. A presença da $H$. pylori na mucosa bucal não teve relação com a severidade da DECHc. As medianas de número de plaquetas $/ \mathrm{mm}^{3}$, leucócitos $/ \mathrm{mm}^{3}$ e neutrófilos $/ \mathrm{mm}^{3}$ no grupo de pacientes TCTH positivos para $H$. pylori não foram estatisticamente diferentes das medianas dos pacientes negativos. Concluindo, o presente estudo mostra um aumento da freqüência da $H$. pylori na mucosa bucal de pacientes submetidos ao TCTH quando comparada com a de um grupo de voluntários não transplantados saudáveis.

DESCRITORES: Helicobacter pylori; Transplante de medula óssea; Mucosa bucal.

\section{INTRODUCTION}

Helicobacter pylori is now accepted as the major cause of chronic active gastritis, duodenal and gastric ulceration ${ }^{4}$, and is associated with the development of gastric carcinoma ${ }^{18}$. $H$. pylori has been detected in dental plaque, saliva and the subgingival region $^{10,15}$, and there have been reports that $H$. pylori strains in the mouth and stomach are identical ${ }^{17}$. The mouth has been considered as an alternative reservoir for $H$. pylori ${ }^{16}$. Although people carrying $H$. pylori have an increased risk of developing peptic

\footnotetext{
* Department of Oral Surgery and Pathology; **Department of Restorative Dentistry - School of Dentistry, Federal University of Minas Gerais.
} 
Correia-Silva JF, Victória JMN, Guimarães ALS, Sá AR, Gomes CC, Almeida HC, Gomez RS. Helicobacter pylori in the oral mucosa of patients submitted to allogeneic haematopoietic stem cell transplantation. Braz Oral Res 2006;20(3):191-5.

ulcers and stomach cancer, it has been recently demonstrated that this bacterium may actually protect humans against diseases of the esophagus ${ }^{2}$.

Haematopoietic stem cell transplantation (HSCT) is being used to treat a variety of malignant and non-malignant diseases. Various complications may interfere with treatment during the neutropenic phase, as well as with engraftment of the new marrow. The most common problems are infections and graft-versus-host disease (GVHD) ${ }^{9}$. The oral cavity is a frequent site of infections, immunologic reactions, and other side effects of HSCT. The oral manifestations subsequent to HSCT include oral lichenoid lesions, mucosal atrophy, erythema, ulcers, and xerostomia ${ }^{13,14}$.

Although it is known that the oral cavity may function as a reservoir for $H$. pylori and that this organism has an important role in the protection or development of diseases of the gastrointestinal mucosa, the impact of immunosuppression on $H$. pylori colonization of the oral mucosa has not yet been addressed. Therefore, the purpose of the present study was to investigate the presence of this bacterium in the oral mucosa of HSCT patients. In addition, as a recent study demonstrated a reduced incidence of acute GVHD of the gut in Chinese carriers of $H$. pylori during allogeneic bone transplantation ${ }^{1}$, we studied the effect of the presence of $H$. pylori on the severity of oral GVHD. Finally, as H. pylori has an influence on the platelet count in HSCT patients ${ }^{20}$, the association between platelets number and the presence of $H$. pylori was also studied.

\section{MATERIALS AND METHODS Subjects and sample collection}

Forty six consecutive patients who underwent HSCT at the Clinical Hospital, Federal University of Minas Gerais, were included in the study. Oral mucosa swabs were taken from three oral sites (labial mucosa, buccal mucosa and tongue) at 100 days after transplantation. The study group was formed by 19 females and 27 males with median age of 27.4 years (range 11 to 56). The main clinical data of the patients are in Table 1 . The swabs were taken with sterile plastic tips, placed immediately in Eppendorf microtubes containing $500 \mu 1$ of Krebs buffer $\left(20 \% \mathrm{NaCl}, 2 \% \mathrm{KCl}, 2 \% \mathrm{CaCl}_{2} 2 \mathrm{H}_{2} \mathrm{O}, \mathrm{MgSO}_{4}, \mathrm{KH}_{2} \mathrm{PO}_{4}\right.$, $\mathrm{C}_{6} \mathrm{H}_{12} \mathrm{O}_{6}$ ), and the pellet obtained after $10 \mathrm{~min}$ of centrifugation at $10,000 \mathrm{~g}$ was stored at $-20^{\circ} \mathrm{C}$ until processing. The same procedure was performed with the oral mucosa swabs of the control group. The control group was composed of 46 non-transplanted healthy
TABLE 1 - Summary of the clinical data of haematopoietic stem cell transplantation patients included in the study.

\begin{tabular}{|c|c|}
\hline Median age, years (range) & 27.4 years $(11-56)$ \\
\hline \multicolumn{2}{|c|}{ Recipient gender } \\
\hline Male, $\mathrm{n}^{\circ}(\%)$ & $27(58.7)$ \\
\hline Female, $\mathrm{n}^{\circ}(\%)$ & $19(41.3)$ \\
\hline \multicolumn{2}{|c|}{ Donor gender } \\
\hline Male, $\mathrm{n}^{\circ}(\%)$ & $24(52.2)$ \\
\hline Female, $n^{\circ}(\%)$ & $22(47.8)$ \\
\hline \multicolumn{2}{|c|}{ Primary disease } \\
\hline Malignant, $\mathrm{n}^{\circ}(\%)$ & $32(69.6)$ \\
\hline Non-malignant, $\mathrm{n}^{\circ}(\%)$ & $14(30.4)$ \\
\hline \multicolumn{2}{|c|}{ Stem cell Source } \\
\hline Blood stem cells, $\mathrm{n}^{\circ}(\%)$ & $20(43.4)$ \\
\hline Bone Marrow, $\mathrm{n}^{\circ}(\%)$ & $26(56.6)$ \\
\hline
\end{tabular}

volunteers attending the Restorative Dentistry Clinic. The sex and age of both groups were matched.

The patient group was conditioned for transplantation according to the following protocol. $\mathrm{Pa}-$ tients received cyclophosphamide $(50 \mathrm{mg} / \mathrm{kg} /$ day for 4 days for patients with aplastic anemia or $60 \mathrm{mg} / \mathrm{kg} /$ day for 2 days for patients with leukemia or lymphoma) and busulfan ( $4 \mathrm{mg} / \mathrm{kg} /$ day for 1 day for patients with aplastic anemia or $4 \mathrm{mg} /$ $\mathrm{kg} /$ day for 4 days for patients with leukemia or lymphoma). Methotrexate and cyclosporin were used for GVHD prophylaxis after allo-HSCT.

The medical records of the patients were reviewed and the following information was retrieved: gender and age of the patient, donor gender, primary disease, stem cell source (bone marrow or blood stem cells), leukocyte, neutrophil and platelet counts. Biopsies of the lower lip were done in patients at +100 day for chronic GVHD staging in the salivary glands as previously described ${ }^{8}$.

The study protocol was approved by the local ethics in research committee, and informed consent was obtained from all the patients, or from the patients' parents if they were under 18 years of age.

\section{DNA isolation}

The DNA extraction was carried out as described by Boom et al..$^{5}(1990)$ and modified as described below. We added $450 \mu \mathrm{l}$ of lyses buffer (6.0 M GuSCN, $65 \mathrm{mM}$ Tris $\mathrm{HCl} \mathrm{pH} 6.4,25 \mathrm{mM}$ EDTA, 1.5\% TritonX-100) and $20 \mu \mathrm{l}$ of silica $\left(\mathrm{SiO}_{2}\right.$, Sigma S-5631) to the microcentrifuge tube containing the oral mucosa 
Correia-Silva JF, Victória JMN, Guimarães ALS, Sá AR, Gomes CC, Almeida HC, Gomez RS. Helicobacter pylori in the oral mucosa of patients submitted to allogeneic haematopoietic stem cell transplantation. Braz Oral Res 2006;20(3):191-5.

swab pellet. The tube was vortexed and incubated for $30 \mathrm{~min}$ at $56^{\circ} \mathrm{C}$, centrifuged at $10,000 \mathrm{~g}$ for $1 \mathrm{~min}$, and the supernatant was discharged. The pellet obtained (DNA adsorbed to the silica) was washed twice with $450 \mu 1$ of washing buffer $(6.0 \mathrm{M}$ GuSCN, $65 \mathrm{mM}$ Tris $\mathrm{HCl}$ ), twice with $70 \%$ ethanol, once with $450 \mu \mathrm{l}$ of acetone and dried at $56^{\circ} \mathrm{C}$ for $10 \mathrm{~min}$. Finally, $100 \mu \mathrm{l}$ of TE buffer (10 mM Tris-HCl pH 8.0, $1 \mathrm{mM}$ EDTA) were added and the solution was incubated at $56^{\circ} \mathrm{C}$ overnight to elute the DNA. After incubation the solution was homogenized and centrifuged at $10,000 \mathrm{~g}$ for 2 minutes and the supernatant containing DNA was transferred to a new tube.

\section{Nested Polymerase Chain Reaction (PCR)}

The PCR reactions were performed as described elsewhere ${ }^{19}$. Six $\mu 1$ of DNA solution were subjected to PCR with 2 sets of primer pairs from a genome of Helicobacter pylori strain 26695. The outer primer pair was 5'CAGTTATTTGGTGGCTACAACCG 3' and 5' CCCATCAATAGAGACGCTTAATCC 3'. The $50 \mu 1$ of reaction mixture containing buffer, Taq DNA polymerase, primers, and deoxyribonucleoside triphosphates were subjected to 40 cycles at $95^{\circ} \mathrm{C}$ for 30 seconds, at $57^{\circ} \mathrm{C}$ for 45 seconds, and at $72^{\circ} \mathrm{C}$ for 30 seconds performed in an Eppendorf-Master Cycler (Eppendorf, Westbury, NY, USA). After the first round of PCR, $2 \mu \mathrm{l}$ of the final product were used as a template for the second PCR with the inner primer pair 5' GCTGTAATTTAAGGGTGGGGGTTG 3' and 5' TGCCGTAATTCAAACTGCAAGCG 3'. The same procedure as described earlier was used except for the annealing temperature, which was $56^{\circ} \mathrm{C}$, and for the use of 30 cycles instead of 40 .

\section{Agarose gel electrophoresis}

Ten microliters of each reaction product were added to $2 \mu$ lof gel loading dye $(0.25 \%$ bromophenol blue, $30 \%$ glycerol, $10 \mathrm{mM}$ EDTA) to visualize the specific product ( 345 base pairs) in a $1.5 \%$ agarose gel, and electrophoresis was carried out using $1 \mathrm{x}$ TAE buffer. DNA fragments were visualized after staining with ethidium bromide $(0.5 \mu \mathrm{g} / \mathrm{ml})$ and using the photo documentation system Vilber Lourmat (Torcy, France). The molecular weight of the DNA was estimated using $100 \mathrm{bp}$ ladder markers.

\section{Statistical analysis}

Statistical analysis was performed by the $c h i^{2}$ and Mann-Whitney tests. A significance level of $\mathrm{P} \leq 0.05$ was used.

\section{RESULTS}

The distribution of positive HSCT patients and controls according to the presence of $H$. pylori is presented in Table 2 . The results demonstrate a positive association between HSCT patients and the presence of $H$. pylori in the oral mucosa $(\rho=0.002)$.

The patients were scored for chronic GVHD of salivary glands and categorized according to the presence of $H$. pylori in the oral mucosa (Table $3)$. There was no association between cGVHD of salivary glands and the presence of $H$. pylori. The median counts of leukocytes $/ \mathrm{mm}^{3}$ and neutrophils $/ \mathrm{mm}^{3}$ in the group of HSCT patients positive for $H$. pylori were not statistically different from those of the patients negative for it (Table 4). Although a decreased count of platelets $/ \mathrm{mm}^{3}$ in the

TABLE 2 - Distribution of HSCT (haematopoietic stem cell transplantation) patients and control subjects according to the presence of Helicobacter pylori in the oral mucosa.

\begin{tabular}{l|c|c}
\hline \hline & $\begin{array}{c}\text { H. pylori }+ \\
\mathrm{n}(\%)\end{array}$ & $\begin{array}{c}\text { H. pylori- } \\
\mathrm{n}(\%)\end{array}$ \\
\hline HSCT $(\mathrm{n}=46)$ & $23(50.0)$ & $23(50.0)$ \\
\hline Control group $(\mathrm{n}=46)$ & $8(17.4)$ & $38(82.6)$ \\
\hline \hline
\end{tabular}

$\rho=0.002$

TABLE 3 - Distribution of haematopoietic stem cell transplantation patients according to cGVHD (chronic graft-versus-host disease) severity of salivary glands and the presence of oral swabs positive for Helicobacter pylori.

\begin{tabular}{l|c|c}
\hline \hline \multicolumn{1}{c|}{ GVHD } & $\begin{array}{c}\text { H. pylori } \\
\mathrm{n}(\%)\end{array}$ & $\begin{array}{c}\text { H. pylori- } \\
\mathrm{n}(\%)\end{array}$ \\
\hline Absence & $5(22.7)$ & $5(22)$ \\
\hline Mild & $14(63.6)$ & $9(39)$ \\
\hline Moderate/Severe & $3(13.7)$ & $9(39)$ \\
\hline \hline
\end{tabular}

$\overline{p=0.13 \text {. In one HSCT patient, cGVHD staging was not possible }}$ due to insufficient sample collection.

TABLE 4 - Median number of leukocytes, neutrophils and platelets in HSCT subjects, positive and negative for $H$. pylori.

\begin{tabular}{l|c|c|c}
\hline \hline & H. pylori + & H. pylori - & P-value \\
\hline $\begin{array}{l}\text { Leukocytes } \\
\left(\text { cels } / \mathrm{mm}^{3}\right)\end{array}$ & 4,680 & 4,500 & 0.95 \\
\hline $\begin{array}{l}\text { Neutrophils } \\
\left(\text { cels } / \mathrm{mm}^{3}\right)\end{array}$ & 2,420 & 2,340 & 0.11 \\
\hline $\begin{array}{l}\text { Platelets } \\
\left.\text { (cels } / \mathrm{mm}^{3}\right)\end{array}$ & 147,000 & 181,000 & 0.10 \\
\hline \hline
\end{tabular}


Correia-Silva JF, Victória JMN, Guimarães ALS, Sá AR, Gomes CC, Almeida HC, Gomez RS. Helicobacter pylori in the oral mucosa of patients submitted to allogeneic haematopoietic stem cell transplantation. Braz Oral Res 2006;20(3):191-5.

group positive for that organism was observed, the difference was not statistically significant.

\section{DISCUSSION}

Helicobacter pylori is a microaerophilic, spiral, gram-negative bacterium that colonizes the human stomach. Although not invasive, it causes inflammation of the gastric mucosa and it is linked to gastric ulcers and carcinomas ${ }^{3}$. In most cases, the acquisition of the infection would be during childhood $^{7}$. Previous studies have identified this microorganism in dental plaque and saliva ${ }^{6,11}$, which would implicate the oral cavity as a potential reservoir for $H$. pylori or as a possible route of transmission to other sites. The possible role of $H$. pylori in the oral cavity is a highly controversial issue.

Although $H$. pylori infection has been reported worldwide, improved sanitation and antibiotics have dropped this bacterium prevalence in the developed world over the past century ${ }^{3}$. Recent evidence has demonstrated that the decline of $H$. pylori has reduced the incidence of stomach cancer but may be triggering an upsurge in diseases of the esophagus, such as acid reflux, Barrett's esophagus (a premalignant lesion) and adenocarcinoma ${ }^{2}$. In addition, $H$. pylori infection can be involved in the pathogenesis of the idiopathic interstitial pneumonia after stem cell transplantation $^{21}$. In the present study a higher presence of $H$. pylori in the oral mucosa of HSCT patients was detected. This fact may be due to poor oral hygiene conditions of the patients during transplantation and/or immunosuppression related to HSCT therapy. It is well known that the oral cavity is a frequent site of local infections and also an important port of entry for systemic infections

\section{REFERENCES}

1. Au WY, Wong RWM, Wong BC, Lie AK, Liang R, Leung AY et al. Reduced incidence of acute graft versus host disease (GVHD) of the gut in Chinese carriers of Helicobacter pylori during allogeneic bone marrow transplantation. Ann Hematol 2004;83:34-7.

2. Blaser MJ. An endangered species in the stomach. Sci Am 2005;292(2):38-45.

3. Blaser MJ, Berg DE. Helicobacter pylori genetic diversity and risk of human disease. J Clin Invest 2001;107(7):767-73.

4. Blaser MJ, Perez-Perez GI, Lindenbaum J, Schneidman D, Van Deventer G, Marin-Sorensen M et al. Association of infection due to Helicobacter pylori with specific upper gastrointestinal pathology. Rev Infect 1991;13 Suppl 8:704-8. in HSCT recipients. The presence of $H$. pylori in the oral cavity may be a risk factor for infection or reinfection of the stomach of these patients ${ }^{12}$. Although the importance of $H$. pylori in the oral cavity has not been established, this finding may be relevant to the gastrointestinal pathology of HSCT patients.

In the present investigation GVHD severity was not associated with the presence of $H$. pylori in the oral mucosa. However, in a study of Chinese carriers of $H$. pylori during allogeneic bone marrow transplantation, a positive association between $H$. pylori carriage and reduced risk of gut acute GVHD was demonstrated ${ }^{1}$. Although a previous study has shown that $H$. pylori infection accelerates recovery of the platelet count after HSCT, possibly by stimulating IL- 6 production ${ }^{20}$, we have not identified any association between platelet, leukocyte and neutrophil counts and the presence of $H$. pylori in the oral mucosa.

\section{CONCLUSION}

The present study showed an increased frequency of $H$. pylori in the oral mucosa of HSCT patients when compared to that of non-transplanted healthy volunteers. The systemic implications related to the presence of this bacterium in the oral mucosa of HSCT patients needs further investigation.

\section{ACKNOWLEDGEMENTS}

This study was supported by grants from the National Council for Scientific and Technological Development $(\mathrm{CNPq})$ and The State of Minas Gerais Research Foundation (FAPEMIG), Brazil. Dr. RS Gomez is a research fellow of CNPq.

5. Boom R, Sol CJ, Salimans MM, Jansen CL, Wertheimvan Dillen EM, van de Noordaa J. Rapid and simple method for purification of nucleic acids. J Clin Microbiol 1990;28(3):495-503.

6. Gebara EC, Pannuti C, Faria CM, Chehter L, Mayer MP, Lima LA. Prevalence of Helicobacter pylori detected by polymerase chain reaction in the oral cavity of periodontitis patients. Oral Microbiol Immunol 2004;19(4):277-80.

7. Gill HH, Majmudar P, Shankaran K, Desai HG. Age-related prevalence of Helicobacter pylori antibodies in Indian subjects. Indian J Gastroenterol 1994;13(3):92-4.

8. Gomez RS, Carneiro MA, Souza LN, Victoria JM, de Azevedo WM, De Marco L et al. Oral recurrent human herpes virus infection and bone marrow transplantation survival. Oral 
Correia-Silva JF, Victória JMN, Guimarães ALS, Sá AR, Gomes CC, Almeida HC, Gomez RS. Helicobacter pylori in the oral mucosa of patients submitted to allogeneic haematopoietic stem cell transplantation. Braz Oral Res 2006;20(3):191-5.

Surg Oral Med Oral Pathol Oral Radiol Endod 2001;91 (5):552-6

9. Jones M, Cray C, Levy RB. Concurrent MCMV infection augments donor antihost-specific activity and alters clinical outcome following experimental allogenic bone marrow transplantation. Transplantation 1996;61(6):856-61.

10. Krajden S, Fuksa M, Anderson J, Kempston J, Boccia A, Petrea $\mathrm{C}$ et al. Examination of human stomach biopsies, saliva and dental plaque for Campylobacter pylori. J Clin Microbiol 1989;27(6):1397-8.

11. Majmudar P, Shah SM, Dhunjibhoy KR, Desai HG. Isolation of Helicobacter pylori from dental plaques in healthy volunteers. Indian J Gastroenterol 1990;9(4):271-2.

12. Miyabayashi H, Furihata K, Shimizu T, Ueno I, Akamatsu T. Influence of oral Helicobacter pylori on the success of eradication therapy against gastric Helicobacter pylori. Helicobacter 2000;5(1):30-7.

13. Nakamura S, Hiroki A, Shinohara M, Gondo H, Ohyama Y, Mouri T et al. Oral involvement in chronic graft-versus-host disease after allogenic bone marrow transplantation. Oral Surg Oral Med Oral Pathol Oral Radiol Endod 1996;82(5):556-63.

14. Nakhleh RE, Miller W, Snover DC. Significance of mucosal vs. salivary gland changes in lip biopsies in the diagnosis of chronic graft-versus-host disease. Arch Pathol Lab Med 1989;113(8):932-4.
15. Nguyen AMH, Engstrand L, Genta RM, Graham DY, El Zaatari FAK. Detection of Helicobacter pylori in dental plaque by reverse transcription-polymerase chain reaction. J Clin Microbiol 1993;31(4):783-7.

16. Shimada T, Ogura K, Ota S, Terano A, Takahashi M, Hamada $\mathrm{E}$ et al. Identification of Helicobacter pylori in gastric specimens, gastric juice, saliva, and faeces of Japanese patients. Lancet 1994;25(343):1636-7.

17. Song Q, Haller B, Schmid RM, Adler G, Bode G. Helicobacter pylori in dental plaque: a comparison of different PCR primer sets. Dig Dis Sci 1999;44(3):479-84.

18. The EUROGAST Study Group. An international association between Helicobacter pylori infection and gastric cancer. Lancet 1993;341(8857):1359-62. Erratum in: Lancet 1993;341(8861):1668.

19. Victoria JM, Kalapothakis E, Silva J de F, Gomez RS. Helicobacter pylori DNA in recurrent aphthous stomatitis. J Oral Pathol Med 2003;32(4):219-23.

20. Wakae T, Takatsuka H, Mori A, Okada M, Fujimori Y, Okamoto $\mathrm{T}$ et al. Influence of Helicobacter pylori on platelets after bone marrow transplantation from unrelated donors. Bone Marrow Transplant 2003;31(6):493-6.

21. Yamaguchi $N$, Takatsuka $H$, Wakae $T$, Okada $M, F u-$ jimori Y, Okamoto T, et al. Idiopathic interstitial pneumonia following stem cell transplantation. Clin Transplant 2003;17(4):338-46. 